DOI: $10.15193 /$ zntj/2019/118/280

\author{
MARTA SAJDAKOWSKA, SYLWIA ŻAKOWSKA-BIEMANS, \\ KRYSTYNA GUTKOWSKA
}

\title{
FOOD OF POLISH ORIGIN AND ITS ATTRIBUTES IN CONSUMER OPINION
}

\begin{abstract}
Su m m a r y
The study included two survey objectives: (1) to define the socio-demographic profile of consumers interested in food perceived as domestic; (2) to determine the consumers' understanding of the concept 'food of Polish origin' and to indicate, which attributes, and to what extent, are attributed to this type of food. A Poland-wide pool of 1000 persons was surveyed in October 2013. The character of the survey research was quantitative; the survey was conducted with the use of a personal CAPI technique (Computer Assisted Personal Interviews). A frequency analysis was carried out; mean values and standard deviations were calculated. A $\chi^{2}$ statistic was applied to determine statistically significant differences among the variables. A one way analysis of variance (ANOVA) and a Tukey's post hoc test were adopted to compare whether or not the differences among the means were statistically significant. It was proved that the 'food of Polish origin' was mostly perceived as a food produced in Poland and from the Polish raw materials. The respondents who highlighted the place of production as a key criterion to indicate the Polish origin of food were over 61 years of age; they had higher education and declared to frequently travel abroad. The women surveyed more frequently appreciated the Polish origin of raw materials as did the oldest respondents and the persons with a higher level of education. The results obtained show that the consumers have confidence in the food they believed to be of the Polish origin and they positively assess it. Also, the results achieved provide some insights into communications targeted at elderly consumers, whose market share increases owing to the aging of the society.
\end{abstract}

Key words: consumer, food of Polish origin, food attributes, consumer ethnocentrism

\section{Introduction}

While taking food purchase decisions, the consumers consider numerous criteria [21], including sensory properties of food, prices and naturalness [17]. Polish consum-

Dr inż. M. Sajdakowska, dr hab. S. Żakowska-Biemans, prof. dr hab. K. Gutkowska, Katedra Organizacji i Ekonomiki Konsumpcji, Wydz. Nauk o Żywieniu Człowieka i Konsumpcji, Szkoła Główna Gospodarstwa Wiejskiego w Warszawie, ul. Nowoursynowska 159 C, 02-776 Warszawa.

Kontakt:marta_sajdakowska@sggw.pl 
ers are more and more concerned with various food quality attributes [21] and, as regards some foods, they are focused on such purchase factors as quality level and country of origin given on the label of a given product [39]. Furthermore, it is also important for the Polish consumers whether or not the product is of Polish origin [21, 26]. In general, positive connotations of the Polish consumers with the domestic food are determined by their ethnocentric tendencies seen as a universal manifestation of the preference for products manufactured within the geographic area of consumer origin $[25,37]$.

In their studies, Shimp and Sharma showed [28] that consumer ethnocentrism implies that purchasing imports is wrong because it is unpatriotic and detrimental to the economy and it results in loss of jobs. Ethnocentric tendencies are negatively correlated with attitudes towards foreign products and purchase intentions [28].

Overall, when socio-demographic determinants are taken into account, age and education are the variables to diversify ethnocentric attitudes. It is noted that older consumers are more often ethnocentric than young consumers [15, 31, 35]. Consumer ethnocentrism is lower among the consumers with higher levels of education [22] and, as the education level increases, the ethnocentric tendency decreases [9]. In addition, the younger and higher-income consumers are less ethnocentric than their older and lower-income counterparts, and men are less so than women [28].

What is more, according to the studies by Kottasz and Bennet [15], Nijssen and Douglas [20], and by Dobrenova et al. [7], the persons who travel and have contact with other cultures adopt ethnocentric attitudes less frequently and they are more open to products of foreign origin. Erdogan and Uzkurt [9] as well as Yeh et al. [36] reported that high levels of consumer ethnocentrism were significantly associated with strongly negative perceptions of foreign products and with very positive perceptions of domestic products.

According to the research on Polish consumers conducted by CBOS (Centrum Badania Opinii Społecznej - Centre for Public Opinion Research), almost half of them take into account the domestic origin of those products during everyday shopping. Referring to the aspects important from the point of view of the concept of 'national/domestic product', the consumers mainly indicate a product that is produced by a Polish company (96\%) and to a less extent a product produced by a Polish company that operates abroad $(40 \%)$ and also a product manufactured in Poland by a foreign company (24\%) [6].

With regard to the food market, those products, which combine the characteristics of local, regional and traditional products, are highly valued by the consumers. They are particularly valued for their natural character and their flavour [10]. Simultaneously, of food quality attributes, the taste and naturalness of organic food that can be per- 
ceived as local food are more important for the consumers than the same attributes of the conventional food products [8].

There is a belief that usually the local food is tastier and of a higher quality. Hence the taste is the most important driver when purchasing food, thus the local origin of a product is in fact a premium asset [11]. Moreover, the consumers positively value locally grown/produced products and they are also willing to pay more for those products [12]. Furthermore, when referring to the traditional food products, the consumers express a strong interest in being informed about the traditional character of them. They strongly link the traditional food products originating from their own country with a high level of quality [19] and some of the consumers underline that those products have a positive effect on their health [24].

In addition, Poland is a country with a strong sense of patriotism where many traditions are maintained and where the traditions such as Easter or Christmas are strongly associated with the traditional food or the food that has the characteristics of being non-industrialized [33].

Furthermore, when describing traditional food products, the consumers name the attributes such as: special taste, a high yet not highly consistent quality, a high environmental friendliness and a good support for the local economy [1]. As regards the organic food, the main reasons why the consumers select and purchase this type of food include, inter alia, healthiness, food safety, superior taste and quality assurance [5]. Moreover, for some consumers, e.g. for those who are interested in organic food, supporting the local economy is also one of the aspects to be considered when choosing food [38].

Taking into account all the available data in the reference literature, the objective of this survey research covered the following: (1) to define the socio-demographic profile of consumers interested in food perceived as domestic; (2) to determine the consumer's understanding of the concept 'food of Polish origin' and to indicate which attributes, and to what extent, are attributed to this type of food.

\section{Material and methods}

A Poland-wide pool of 1000 persons was surveyed in October 2013. The survey was quantitative in character and it was carried out with the use of a CAPI technique (Computer Assisted Personal Interviews) and a random-stratified sampling method based on the address directory of the Polish Central Statistical Office. The consumers older than 21 years were considered mature enough to take individual food purchase decisions, therefore this group of respondents participated in the survey. Moreover, the sampling met the requirement of representativeness of the general Polish population with regard to the persons aged 21 years and more in terms of the gender and age. Only the persons who declared to purchase food for their households were qualified to par- 
ticipate in the survey. The women comprised $53.7 \%$ and the men $46.3 \%$ of the total sample. Over $1 / 3$ of the respondents were the persons aged between 51 and 60 $(34.4 \%)$. As far as the education was concerned, the persons with primary and vocational education comprised nearly $2 / 5$ of the respondents $(37.8 \%)$ and the persons with secondary education $-35.4 \%$. Almost $1 / 3$ of the survey participants evaluated their financial standing as good or very good $(26.6 \%$ and $2.9 \%$, respectively) and every tenth respondent as bad or very bad (10.5\% and $1.2 \%$, respectively). Over half of the respondents claimed they did not travel abroad within the past 3 years or at all $(30.8 \%$ and $26.6 \%$, respectively). A detailed description of the survey sample is presented in Tab. 1. Only some selected issues covered by the survey research are presented in this article and this is in line with the specified survey objective.

The questionnaire used in the survey included the questions on the following: (1) the concept of 'food of Polish origin', (2) attributes of food perceived as domestic, (3) selected items from the CETSCALE (Consumer Ethnocentric Tendencies Scale) [28] and socio-demographic characteristics of the population.

To identify how the respondents conceptualize the notion 'food of Polish origin', they were asked to assess how strongly they agreed with the 4 statements describing: (1) the place of food production (Poland), (2) the origin of raw materials, (3) the domestic origin of the company and (4) the country the workers of a company come from. Subsequently, the respondents were requested to assess how strongly they agreed with the statements describing a food referred to as the food of Polish origin. In order to accomplish the survey research objective, the participants were asked to indicate to what extent they agreed with an opinion that the Polish food: (1) is of high quality, (2) is tasty, (3) looks attractive, (4) is easy to prepare, (5) is readily available, (6) has high nutritional value, (7) is cheap and (8) supports the local economy. The level of agreement as regards the concept of 'food of Polish origin' and the attributes assigned to it was measured with the use of a 7-point scale, where 1 was - 'I strongly disagree' and 7 - 'I strongly agree'.

Also, in the survey research, there was measured the intensity of the respondents' ethnocentrism. Twelve selected statements from the original CETSCALE (i.e. a 7-point Consumer Ethnocentric Tendencies Scale were adopted for that purpose; here 1 means - 'I strongly disagree' and 7 means - 'I strongly agree') [28].

The statements used in this survey were as follows: (1) It is not right to purchase foreign products; (2) A real Pole should always buy Polish-made products; (3) Poles should not buy foreign products, because this hurts Polish business and causes unemployment; (4) Polish consumers who purchase products made in other countries are responsible for putting their fellow Poles out of work; (5) Purchasing foreign-made products is un-Polish; (6) Only those products that are unavailable in Poland should be 
Table 1. Description of respondents comprising selected socio-demographic characteristics, travels abroad and level of consumer ethnocentrism

Tabela 1. Charakterystyka respondentów $\mathrm{z}$ uwzględnieniem wybranych cech socjodemograficznych, wyjazdów za granicę oraz poziomu etnocentryzmu konsumenckiego

\begin{tabular}{|c|c|c|}
\hline Socio-demographic characteristics / Charakterystyka socjodemograficzna & $\mathrm{N}$ & {$[\%]$} \\
\hline \multicolumn{3}{|l|}{ Gender / Płeć } \\
\hline female / kobiety & 537 & 53.7 \\
\hline male / mężczyźni & 463 & 46.3 \\
\hline \multicolumn{3}{|l|}{ Age [years] / Wiek [w latach] } \\
\hline $21-30$ & 213 & 21.3 \\
\hline $31-40$ & 179 & 17.9 \\
\hline $41-50$ & 135 & 13.5 \\
\hline $51-60$ & 344 & 34.4 \\
\hline 61 and more / 61 i więcej & 129 & 12.9 \\
\hline \multicolumn{3}{|l|}{ Education / Wykształcenie } \\
\hline primary, vocational / podstawowe, zawodowe & 378 & 37.8 \\
\hline secondary / średnie & 354 & 35.4 \\
\hline $\begin{array}{l}\text { bachelor's degree, engineer's degree, higher education } \\
\text { licencjackie, inżynierskie, wyższe }\end{array}$ & 268 & 26.8 \\
\hline \multicolumn{3}{|c|}{ Subjective assessment of financial standing / Subiektywna ocena sytuacji finansowej } \\
\hline very bad / bardzo zła & 12 & 1.2 \\
\hline $\mathrm{bad} / \mathrm{zła}$ & 105 & 10.5 \\
\hline neither good nor bad / ani dobra ani zła & 588 & 58.8 \\
\hline good / dobra & 266 & 26.6 \\
\hline very good / bardzo dobra & 29 & 2.9 \\
\hline \multicolumn{3}{|l|}{ Travels abroad / Wyjazdy za granicę } \\
\hline more often than once a year / częściej niż raz na rok & 83 & 8.3 \\
\hline once a year / raz w roku & 118 & 11.8 \\
\hline less than once a year / rzadziej niż raz na rok & 225 & 22.5 \\
\hline $\begin{array}{l}\text { no travels within the last } 3 \text { years } \\
\text { brak wyjazdu w ciągu ostatnich } 3 \text { lat }\end{array}$ & 308 & 30.8 \\
\hline no travels at all / w ogóle brak wyjazdu & 266 & 26.6 \\
\hline \multicolumn{3}{|l|}{ Level of consumer ethnocentrism / Poziom etnocentryzmu konsumenckiego } \\
\hline low / niski & 241 & 24.1 \\
\hline medium / średni & 536 & 53.6 \\
\hline high / wysoki & 223 & 22.3 \\
\hline
\end{tabular}

Source / Źródło: the author’s own study / badania własne

imported; (7) It is always best to purchase Polish products; (8) Foreign products should be taxed heavily to reduce their entry into Poland; (9) There should be very little trading or purchasing of goods from other countries unless out of necessity; (10) Curbs 
should be put on all imports; (11) Foreigners should not be allowed to put their products on our markets; (12) Buy Polish-made products. Keep Poland working.

The calculated level of consumer ethnocentrism ranged from 12 to 84; on the basis of that level, it was possible to assign the respondents into one of the three categories depending on the intensity of consumer ethnocentrism, i.e. the consumers with low (12 - 35 points), medium (36 - 60 points) and high ethnocentrism (61 - 84 points).

While analyzing the data, a frequency analysis was carried out, mean values and standard deviations were calculated. To determine statistically significant differences among the variables, a $\chi^{2}$ statistic was calculated (level of significance $\mathrm{p}<0.05$ ). To verify whether or not the difference between the means is significant, a one way ANOVA and a Tukey's post hoc test were adopted at a significance level of $\mathrm{p}<0.05$. The statistical analysis of the results was performed with the use of IBM SPSS Statistics 24.0 statistical software.

\section{Results and discussion}

\section{Food perceived as domestic products - fundamentals of the concept}

When defining the term 'food of Polish origin' as the food produced in Poland $\left(\chi^{2}\right.$ test), it was found that the respondents' opinions were statistically significantly differentiated by the gender $(p=0.026)$. Furthermore, the respondents' opinions on the Polish origin of raw materials were significantly differentiated by the gender and education ( $p=0.004$ and $p=0.048$, respectively). The respondents' definitions of the term 'food of Polish origin' as the food produced by a company of domestic origin were statistically significantly differentiated by the gender of the respondents $(p=0.008)$, their age $(p=0.035)$, and their level of education $(p=0.002)$. The opinion concerning the production of food by a company that employs Polish workers was statistically significantly impacted by the education $(\mathrm{p}=0.035)$.

On the basis of mean ratings (ANOVA, $\mathrm{p}<0.005$ ), it was found that all the statements describing the food of Polish origin received higher than neutral ratings from the participants (4). Among the persons aged 61 and more, the level of belief that the food of Polish origin was produced in Poland was statistically significantly higher than that of the persons aged $51-60$. Compared with the persons with primary or vocational education, the persons with at least a bachelor's degree agreed with this opinion to a statistically significantly greater extent as did the persons who went abroad more often than once a year in comparison to the persons who did not travel at all (Tab. 2).

As regards the origin of raw materials (food produced from the Polish raw materials), significantly higher levels of agreement were declared by the women than by the men. Moreover, significantly higher ratings were provided by the oldest respondents than by the youngest (21 - 30 years old) and those aged $41-50$ and $51-60$. The per- 
sons with at least a bachelor's degree agreed with this opinion significantly more strongly than those with primary or vocational education.

Table 2. Definitions of food of Polish origin comprising selected socio-demographic variables, profiles of travels abroad and level of consumer ethnocentrism

Tabela 2. Definiowanie żywności pochodzenia polskiego z uwzględnieniem wybranych cech socjodemograficznych, charakterystyki dotyczącej wyjazdów za granicę oraz poziomu etnocentryzmu konsumenckiego

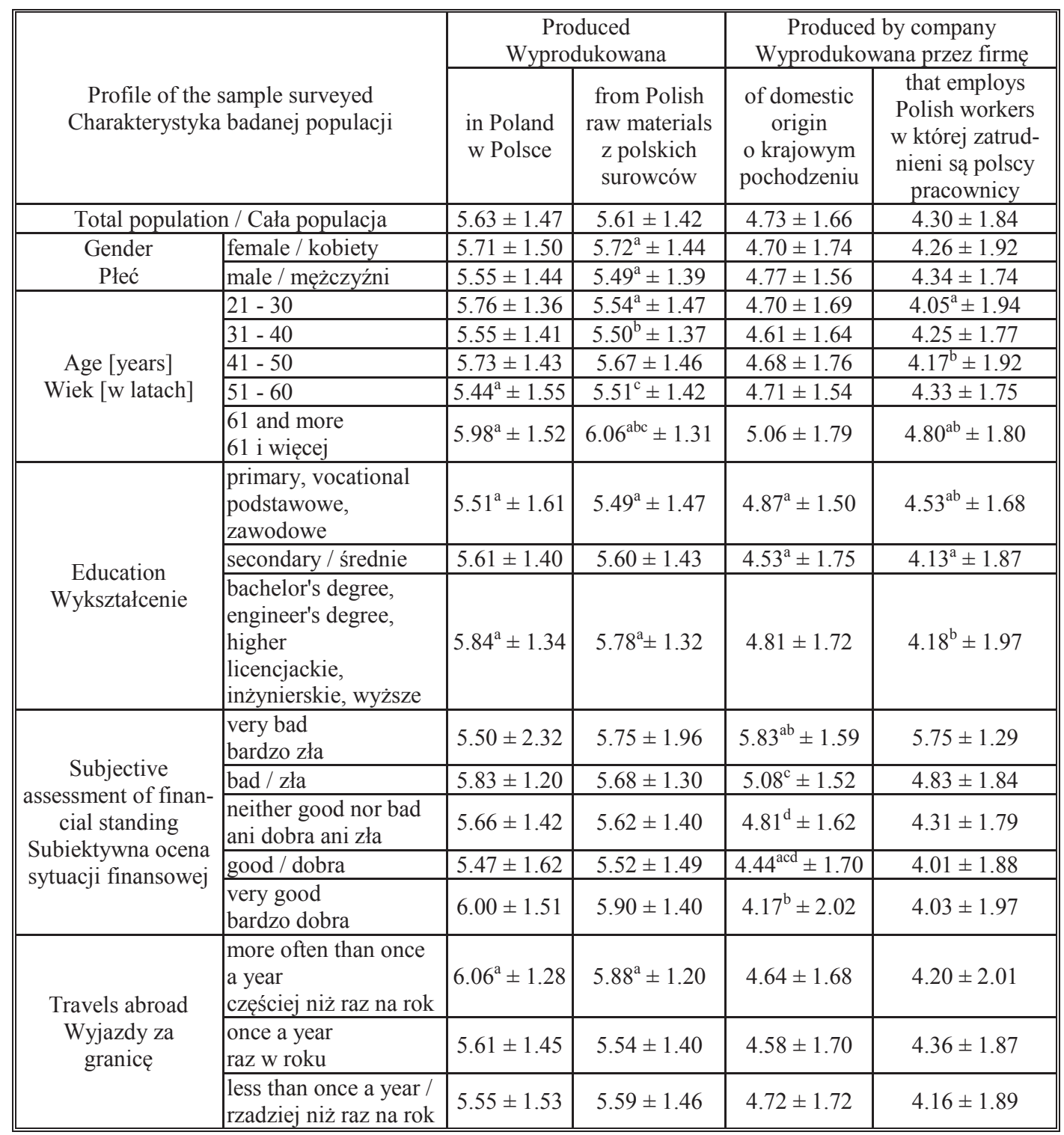




\begin{tabular}{||c|l|c|c|c|c||}
\hline \hline & $\begin{array}{l}\text { no travel within the } \\
\text { last 3 years } \\
\text { brak wyjazdu w ciągu } \\
\text { ostatnich 3 lat }\end{array}$ & $5.68 \pm 1.44$ & $5.84^{\mathrm{b}} \pm 1.30$ & $4.74 \pm 1.65$ & $4.30 \pm 1.76$ \\
\cline { 2 - 6 } & $\begin{array}{l}\text { no travel at all / w } \\
\text { ogóle brak wyjazdu }\end{array}$ & $5.53^{\mathrm{a}} \pm 1.51$ & $5.31^{\mathrm{ab}} \pm 1.54$ & $4.82 \pm 1.60$ & $4.41 \pm 1.82$ \\
\hline $\begin{array}{c}\text { Level of consumer } \\
\text { ethnocentrism } \\
\begin{array}{c}\text { Poziom } \\
\text { etnocentryzmu } \\
\text { konsumenckiego }\end{array}\end{array}$ & low / niski & $\begin{array}{c}5.68^{\mathrm{ab}} \pm \\
1.71\end{array}$ & $5.90^{\mathrm{a}} \pm 1.52$ & $4.24^{\mathrm{ab}} \pm 1.92$ & $3.63^{\mathrm{ab}} \pm 2.04$ \\
\cline { 2 - 6 } & high / wysoki & $\begin{array}{c}5.41^{\mathrm{ac}} \pm \\
1.42\end{array}$ & $5.29^{\mathrm{ab}} \pm 1.38$ & $4.64^{\mathrm{ac}} \pm 1.44$ & $4.19^{\mathrm{ac}} \pm 1.60$ \\
\cline { 2 - 6 } & $\begin{array}{c}1.20 \\
\mathrm{~b}\end{array}$ & $6.07 \pm 1.21$ & $5.48^{\mathrm{bc}} \pm 1.60$ & $5.28^{\mathrm{bc}} \pm 1.76$ \\
\hline
\end{tabular}

Explanatory notes / Objaśnienia:

Table shows mean values \pm standard deviation / W tabeli przedstawiono wartości średnie \pm odchylenie standardowe; $\mathrm{n}=1000 ; \mathrm{a}, \mathrm{b}, \mathrm{c}-$ mean values in columns and denoted by the same letters differ statistically significantly $(\mathrm{p}<0.05)$ / wartości średnie w kolumnach oznaczone tymi samymi literami różnią się statystycznie istotnie $(\mathrm{p}<0,05)$.

Source / Źródło: the author's own study / badania własne

The average assessments of agreement with the statement that the food of Polish origin was produced from the Polish raw materials were significantly higher in the case of the respondents who declared to travel more often than once a year than in the case of those who did not travel abroad at all. At the same time, the persons that did not travel abroad within the last 3 years agreed with this opinion significantly more strongly than those who were never abroad so far (Tab. 2).

When weighing up the mean values and compared to the respondents with secondary education, it was found that the persons with primary and vocational education declared significantly more firmly that the food of Polish origin was produced by a company of domestic origin (Tab. 2). The persons who evaluated their financial situation as very bad significantly more strongly agreed with this statement compared to the persons in a good and very good financial situation.

In turn, compared to the persons in a good financial situation, the persons who evaluated their financial standing as bad agreed significantly more strongly with the statement that that food was produced by a company of domestic origin. This shows that the persons with a lower level of education and a worse income-related standing put a greater emphasis on the Polish origin of a company as far as the categorisation of a product as Polish is concerned; this fact may have implications for the effective communication of those issues to the consumers having this type of socio-demographic profile. In comparison to the persons aged over 61, those aged 21 - 30 and 41 - 50 significantly less strongly agreed with the opinion that the food of Polish origin was manufactured by a company that employed Polish workers. Taking education into account, it is apparent that the persons with the lowest level of education (primary and vocational) significantly more strongly agree with this opinion both in comparison to the per- 
sons with secondary education and to the respondents with at least a bachelor's/engineer's degree.

\section{Significance of consumer ethnocentrism for the concept of 'food of Polish origin}

Based on the data obtained, it can be concluded that the level of consumer ethnocentrism differentiated the respondents' agreements with the statements about all the attributes describing the food perceived as 'food of Polish origin', which were suggested in the survey research. In comparison to the other two test groups, the respondents with the highest level of ethnocentrism significantly more strongly agreed that the food of Polish origin is a food produced in Poland, produced by a company of domestic origin, and by a company that employed Polish workers (Tab. 2). The persons from the group of the respondents with the highest ethnocentrism significantly more strongly agreed with the opinion that the food of Polish origin was produced from the Polish raw materials compared to the respondents characterized by medium ethnocentrism. Also, it should be pointed out that the respondents with the lowest level of ethnocentrism significantly more strongly agreed with the opinion that the food of Polish origin was produced from the Polish raw materials compared to the consumers showing medium ethnocentrism; this fact may indicate that a low level of ethnocentrism does not necessarily result in rejection/depreciation of the food perceived as domestic.

\section{Attributes of food perceived as 'food of Polish origin' according to the respondents}

In accordance with the objective set out in the survey research, the respondents were requested to indicate how strongly they agreed that the food perceived as 'food of Polish origin' had the selected attributes. On the basis of the comparison of mean values, it was found that the respondents indicated the taste, support for the local economy and high quality as the most important attributes of food perceived as 'food of Polish origin' (Tab. 3).

Provided the age, gender and education are taken into account, no statistically significant differences occur between mean ratings of the statements that the food of Polish origin is of high quality, tasty, looks attractive and is easy to prepare (ANOVA, $\mathrm{p}>0.05)$.

However, as regards the statement that the food of Polish origin is of high quality, subjective assessment of financial standing significantly differentiated the respondents' opinions. The persons who assessed their financial situation as very bad significantly more strongly agreed with that opinion than the persons in a very good financial situation. And the persons who assessed their financial standing as bad more strongly agreed with that statement than those who described their situation as 'neither good nor bad' and as good or very good. 


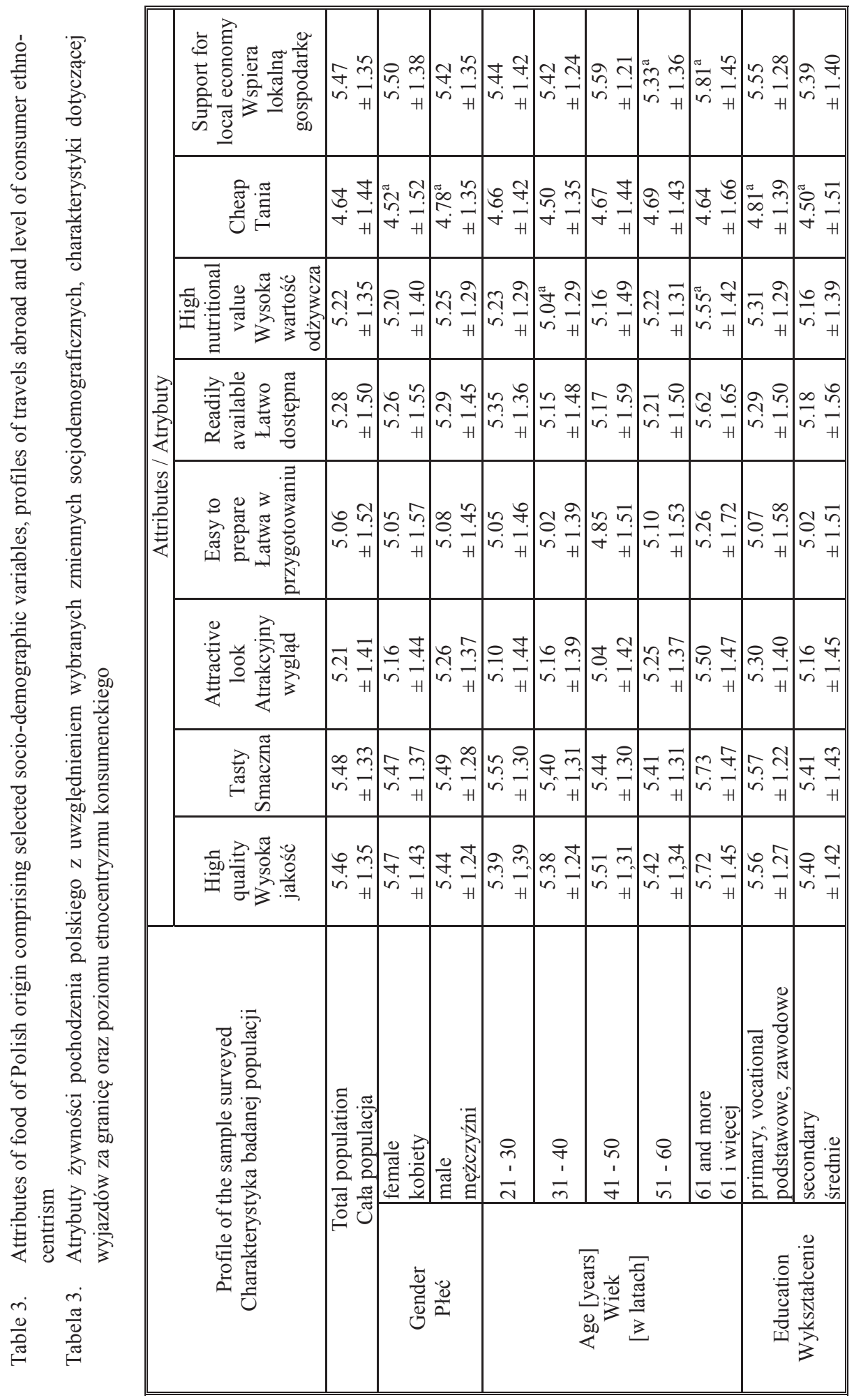




\begin{tabular}{|c|c|c|c|c|c|c|c|c|c|c|c|c|c|}
\hline 官 & 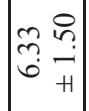 & 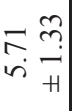 & $\stackrel{\infty}{i} \underset{i}{\stackrel{n}{\rightarrow}}$ & 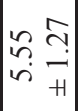 & 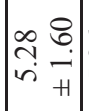 & $\mid$ & 殸 & in $\frac{5}{2}$ & 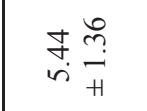 & $\begin{array}{ccc}\vec{n} & 3 \\
i n & 3\end{array} \mid$ & 离 & 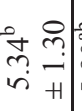 & 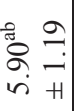 \\
\hline 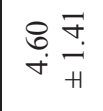 & 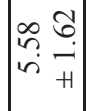 & 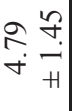 & 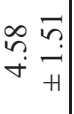 & 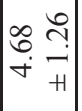 & 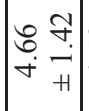 & 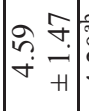 & $\mid$ & 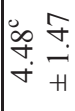 & 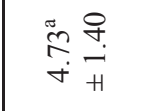 & 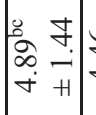 & 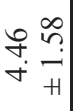 & 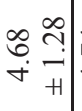 & 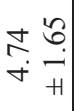 \\
\hline$\stackrel{\infty}{\dot{n}} \stackrel{\infty}{+}_{+}^{\infty}$ & 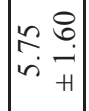 & 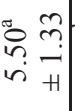 & 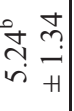 & 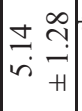 & 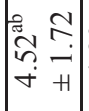 & 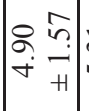 & $\begin{array}{ll}\overline{3} & 0 \\
& -1\end{array}$ & त) & $\stackrel{\infty}{m} \underset{n}{\stackrel{\infty}{n}}$ & 它 & 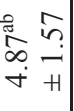 & 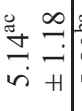 & 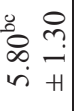 \\
\hline$\stackrel{\infty}{\stackrel{\infty}{n}} \underset{+}{+}$ & 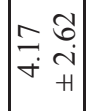 & 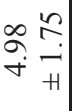 & 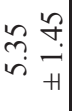 & 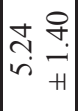 & 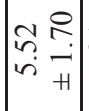 & 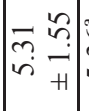 & 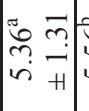 & 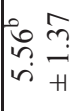 & 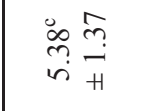 & 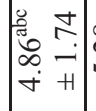 & 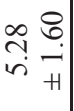 & 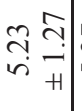 & 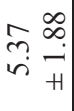 \\
\hline$\stackrel{\circ}{\stackrel{9}{\stackrel{f}{*}}} \underset{+}{+}$ & $\left.\begin{array}{lll}0 & \infty \\
0 & \infty \\
0 & n \\
n & i \\
m & H\end{array}\right]$ & 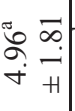 & 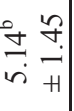 & 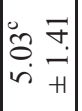 & 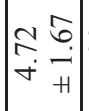 & 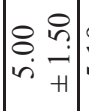 & 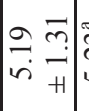 & 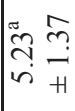 & 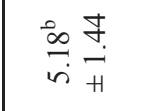 & 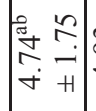 & 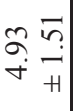 & $\left|\begin{array}{cc}\vec{a} & \vec{m} \\
\dot{\sim} & \overrightarrow{1}\end{array}\right|$ & $\begin{array}{ll}\infty & \frac{\hat{a}}{n} \\
\dot{n} & \frac{H}{H}\end{array}$ \\
\hline$\stackrel{\Delta}{\dot{n}} \underset{+}{\stackrel{\infty}{m}}$ & 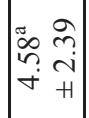 & 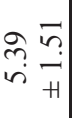 & तु & 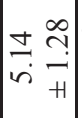 & 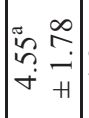 & 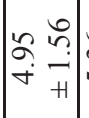 & 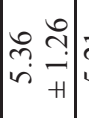 & 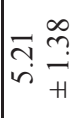 & ते & 的 & 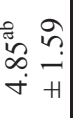 & & 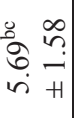 \\
\hline 守点 & 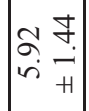 & 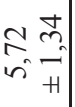 & 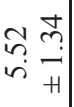 & 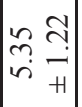 & $\left|\begin{array}{c|c}8 & 0 \\
\dot{n} & \infty \\
+1\end{array}\right|$ & 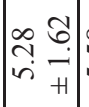 & $\left.\mid \begin{array}{lll}\infty & 0 \\
n & = \\
n & -1\end{array}\right]$ & in & 安 & 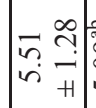 & 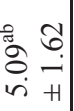 & 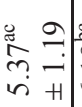 & 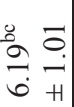 \\
\hline$\stackrel{\infty}{\stackrel{\infty}{n}} \underset{i}{\stackrel{n}{+}}$ & 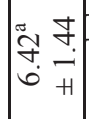 & 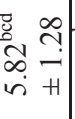 & 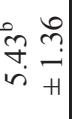 & 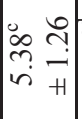 & 俤 & 完 & 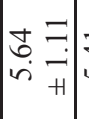 & Fi & 染 & 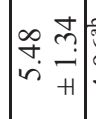 & 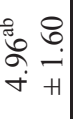 & 总 & 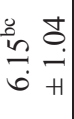 \\
\hline 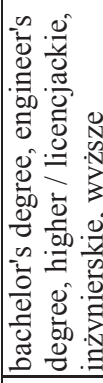 & 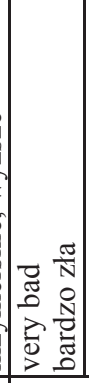 & $\begin{array}{l}\frac{\pi}{N} \\
\frac{\vec{J}}{\tilde{J}} \\
\end{array}$ & 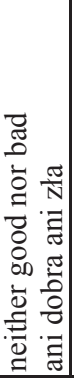 & $\begin{array}{l}\pi \\
0 \\
0 \\
0 \\
0 \\
0 \\
0 \\
0 \\
0.0\end{array}$ & \begin{tabular}{|c|c|} 
& \\
& \\
& \\
& \\
& \\
0 & 0 \\
0 & 0 \\
0 & 0 \\
0 & 0 \\
2 & 0 \\
0 & 0 \\
& 0 \\
\end{tabular} & 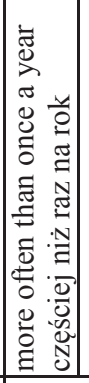 & 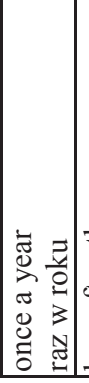 & 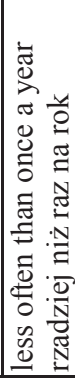 & 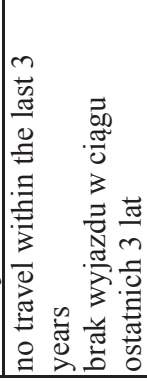 & 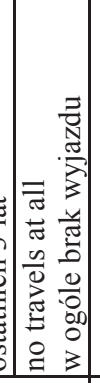 & 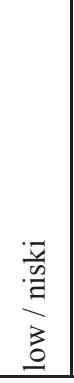 & 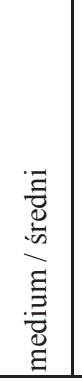 & 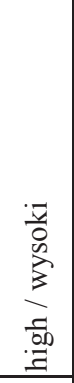 \\
\hline & & 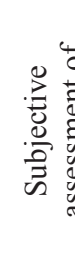 & 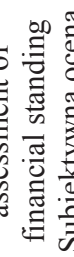 & 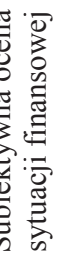 & & & & 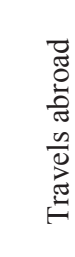 & 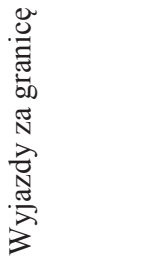 & & 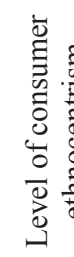 & 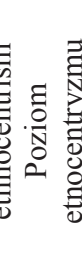 & \\
\hline
\end{tabular}


Also, the subjective assessment of one's financial standing had a statistically significant influence on the opinions about the attractive look of the food of Polish origin. The persons who assessed their financial situation as very bad agreed significantly more strongly with the opinion that the food of Polish origin looks attractive than the persons in a very good financial situation.

As regards the convenience of preparation (i.e. the food was described as 'easy to prepare'), the respondents who rated their financial situation as very bad less strongly agreed with that opinion than those who described their situation as bad, neither good nor bad or as good (Tab. 3).

Also, the declared frequency of travelling abroad significantly impacted the respondents' opinions on the ease of food preparation. Compared to the persons who did not travel abroad at all, the persons who travelled abroad less frequently than once a year or did not travel within the last 3 years preceding the survey significantly more strongly agreed with the opinion that the food of Polish origin was easy to prepare.

Most likely, the ratings of the respondents in a very bad financial situation and of those who did not go abroad at all, are mainly linked with the fact that they are experienced in preparing and consuming food of this category in their households and also with the fact that they perceive this food as a so-called fully domestic food and that they are probably less experienced in consuming foods of foreign origin.

Within the framework of this survey research, also the declared frequency of travelling abroad differentiated the respondents' opinions on the availability of food of Polish origin (i.e. the food that is described as 'readily available'). The persons travelling 'once a year', 'less frequently than once a year', and those declaring 'no travels within the last 3 years' more strongly agreed with the statement about the availability of this type of food in comparison to the persons not travelling abroad at all (Tab. 3).

On the basis of the comparison of mean values, it was found that the age and subjective perception of one's financial situation significantly differentiated the level of agreement with the claim that the food of Polish origin was characterized by a high nutritional value. The persons aged 31 - 40 less strongly agreed with this opinion compared to the respondents aged 61 or more.

The persons who assessed their financial situation as bad agreed with this opinion significantly more strongly than the respondents in a very good financial situation. The respondents who were unable to assess their financial standing declared significantly lower ratings compared to the persons in a very good financial situation.

Based on the analysis of the data, it can be concluded that the gender, education and declared frequency of travelling abroad significantly differentiated mean ratings of the statement that the food of Polish origin was cheap. The men significantly more strongly agreed with that opinion compared to the women; the same was found in the 
case of the persons with primary and vocational education compared to those with secondary education.

The respondents who declared no travels abroad within the last 3 years and no travels abroad at all agreed to the greatest extent with the statement that the food of Polish origin was cheap. Thus, it is worth noting that the persons travelling abroad once a year agreed with this opinion less strongly than the respondents not travelling in the last 3 years or not travelling at all. The persons travelling less frequently than once a year agreed less strongly with the opinion that the food of Polish origin was cheap than the respondents not travelling at all.

As regards the statement that the food of Polish origin supported the local economy, the respondents' age had a statistically significant differentiating effect; the oldest respondents, i.e. aged 61 years or more, significantly more strongly agreed with this opinion than those aged $51-60$.

Significance of consumer ethnocentrism for the assessment of the attributes of 'food of Polish origin'

Based on the analysis of the impact of ethnocentrism on the assessment of the attributes of food perceived as Polish, it can be stated that its intensity significantly influenced the opinions on the quality, taste, appearance, nutritional value and support for the local economy (Tab. 3). The persons with the highest level of ethnocentrism significantly more strongly agreed with the opinion that the food of Polish origin was of high quality, tasty, looked attractive and had a high nutritional value in comparison to the persons with the lowest and medium level of ethnocentrism. At the same time, compared to the respondents with the lowest level of ethnocentrism, the respondents with medium ethnocentrism rated significantly higher the above mentioned attributes of the food perceived as Polish (Tab. 3).

As regards the opinion on supporting the local economy by way of purchasing the food referred to as 'food of Polish origin', the respondents with the highest level of ethnocentrism significantly more confidently claimed that the food of Polish origin supported the local economy compared to those with the lowest and medium level of ethnocentrism. There were no differences between the persons with low and medium level of ethnocentrism (Tab. 3).

\section{Discussion}

Summarizing the results obtained in the survey research as far as defining the product of Polish origin is concerned, it was noted that the older persons with a higher level of education and who declared to travel abroad more frequently perceived the Polish food mainly through the prism of products produced in Poland and from the Polish raw materials. However, the persons with a lower level of education and in 
a bad financial situation slightly more frequently believed that the food of Polish origin was produced by national companies. In addition, it should be highlighted that the respondents with the lowest level of education more often agreed with the opinion that such food came from the companies that employed Polish workers. In comparison to the other groups covered by the survey research, the respondents with a high level of ethnocentrism emphasized the importance of the place of (domestic) production and the domestic origin of the company and its staff. This finding is in line with the findings by Szromnik [30] on consumer ethnocentrism. In their research on socioeconomic profile of consumers with relation to ethnocentric tendencies, Rašković et al. [23] reported that in some markets the young-adult consumers scored low on the scale of consumer ethnocentrism. Other research revealed that the level of ethnocentrism was higher among older consumers [25, 31, 35].

In the authors' own study, it was found that the persons aged 21 - 30 and $41-50$ agreed more frequently with the opinion that the food of Polish origin was produced by a company that employed Polish workers than the persons aged 61 and more. If the education is taken into account, it is evident that the persons with the lowest level of education (primary and vocational) significantly more often agreed with this opinion both in comparison to the respondents with secondary education and to the respondents with at least a bachelor's/engineer's degree. The findings obtained in this survey research are in line with the results presented by Memery et al. [18] and Vanhonacker et al. [34]; they suggest that the concern for local businesses/jobs and economy may be more pronounced among, inter alia, older persons and those with a lower level of education who are bound to traditional values; such a conclusion arises from the research on the traditional and local food. In general, Bernabéu et al. [3] as well as Erdogan and Uzkurt [9] reported that the shoppers with a high level of consumer ethnocentrism are less educated and earn lower incomes than those with a low level of ethnocentrism. In the authors' own study, it was confirmed that the level of education and income were the variables to differentiate the ethnocentric tendencies among Poles. The origin of raw materials may influence consumer's decision processes particularly in the case of specific food categories such as traditional and regional products. In their cross-cultural studies in the selected European countries, including Poland, Vanhonacker et al. [32] indicated that it was important for the consumers interested, for example in traditional food, to have access to information confirming the origin of raw materials the food was made from.

Referring to the perception of food quality, the authors demonstrated that the perception of quality attributes of the food of Polish origin was dominated by the sensory aspects and the support for local economy. Based on the analysis of the impact of ethnocentrism on the assessment of the attributes of food perceived as Polish, it can be concluded that its intensity significantly influences opinions on the selected attributes 
of food. In comparison to other respondents, the respondents with the highest level of ethnocentrism more strongly agreed with the opinion that the food of Polish origin was of high quality, tasty, looks attractive and has high nutritional value. Smyczek and Glowik [29] suggested that the consumer ethnocentrism may arise from economic motives, such as the obligation to buy domestic products and to protect the local labour market. Also Bianchi and Mortimer [4] indicated that the attitude linked with the support for local agribusiness and consumer ethnocentrism positively influences the consumption of local food. Simultaneously, the consumers with regiocentric tendencies and social commitment display greater propensity to purchase products from their own region [16]. Also Josiassen et al. [14] reported that men are less loyal than women when it comes to buying products from their own country, which, in their case, results from the lower impact of consumer ethnocentrism on the propensity to purchase products.

Based on the analysis of the reference literature, it can be concluded that as regards the behaviour of companies on the market, the domestic companies should stress that their brands and products are local/native in order to increase the positivity of opinions based on consumer ethnocentrism and to raise the propensity of consumers to purchase their products. On the other hand, the foreign companies should avoid indicating, directly, their international character in marketing communications and instead they should highlight, inter alia, the cooperation with local businesses [13]. Then again, the consumers can simultaneously identify with a regional identity, a national and supranational identity, and with being a global citizen [2]. In general, the more similarities between the countries exist, the more complex the knowledge about other products in those countries will be. Therefore, indicating the country of origin is advantageous for exporting the products originating from a country considered to be economically, politically or culturally similar to the target market [27].

\section{Conclusions}

1. 'Food of Polish origin' is predominantly perceived as the food produced in Poland and from the Polish raw materials. The respondents who highlighted the place of production as a key criterion to indicate the Polish origin of food were aged 61 years and more, they had higher education and they declared frequent travels abroad. Contacts with other cultures and experiences gained while travelling may contribute to the emphasis this consumer group adds on the place of production regarded as a key criterion of the Polish origin.

2. To a greater extent, the Polish origin of raw materials was appreciated by the women, the oldest respondents and the persons with a higher level of education. On the other hand, the persons in a difficult financial situation stressed the aspect related to the domestic origin of the capital engaged in the production of food, 
whereas the elderly persons and those with a lower level of education stressed the importance of native origin of the employees in a company.

3. The consumers have confidence in the food perceived as Polish, they assess it positively and mainly indicate that it is of high quality, it is tasty and it supports the local economy; they also claim that it is relatively easy to prepare and readily available.

The research survey financed by the Polish Ministry of Science and Higher Education within the funds of Faculty of Human Nutrition and Consumer Sciences, Warsaw University of Life Sciences (WULS), for scientific research.

Praca finansowana przez Ministerstwo Nauki i Szkolnictwa Wyższego w ramach środków na utrzymanie potencjału badawczego Wydziału Nauk o Żywieniu Człowieka $i$ Konsumpcji, $S G G W w$ Warszawie.

\section{Literatura}

[1] Almli V.L., Verbeke W., Vanhonacker F., Næs T., Hersleth M.: General image and attribute perceptions of traditional food in six European countries. Food Qual. Prefer., 2011, 22(1), 129-138.

[2] Bartsch F., Riefler P., Diamantopoulos A.: A taxonomy and review of positive consumer dispositions toward foreign countries and globalization. J. Int. Marketing, 2016, 24 (1), 82-110.

[3] Bernabéu R., Prieto A., Díaz M.: Preference patterns for wine consumption in Spain depending on the degree of consumer ethnocentrism. Food Qual. Prefer., 2013, 28(1), 77-84.

[4] Bianchi C., Mortimer G.: Drivers of local food consumption: A comparative study. Brit. Food J., 2015, 117 (9), 2282-2299.

[5] Bryła P.: Organic food consumption in Poland: Motives and barriers. Appetite, 2016, 105, 737-746.

[6] Centrum Badania Opinii Społecznej: Patriotyzm gospodarczy. [on line]. CBOS, 2017. Dostęp w Internecie [10.02.2019]: http://www.cbos.pl/SPISKOM.POL/2017/K_143_17.PDF

[7] Dobrenova F.V., Grabner-Kräuter S., Terlutter R.: Country-of-origin (COO) effects in the promotion of functional ingredients and functional foods. Eur. Manag J., 2015, 33(5), 314-321.

[8] Doležalová H., Pícha H., Navrátil J., Vesela M., Švec R.: Perception of quality in decision making regarding purchase of organic food. Quality - Access to Success, 2016, 17 (153), 86-91.

[9] Erdogan B.Z., Uzkurt C.: Effects of ethnocentric tendency on consumers' perception of product attitudes for foreign and domestic products. Cross Cultural Management, 2010, 17 (4), 393-406.

[10] Fernández-Ferrín P., Calvo-Turrientes A., Bande B., Artaraz-Miñón M., Galán-Ladero M.M.: The valuation and purchase of food products that combine local, regional and traditional features: The influence of consumer ethnocentrism. Food Qual. Prefer., 2018, 64, 138-147.

[11] Feldmann C., Hamm U.: Consumers' perceptions and preferences for local food: A review. Food Qual. Prefer., 2015, 40, 152-164.

[12] Gracia A.: Consumers' preferences for a local food product: A real choice experiment. Empir. Econ., 2014, 47, 111-128.

[13] Guo G., Zhou X.: Consumer ethnocentrism on product judgment and willingness to buy: Metaanalysis. Soc. Bahav. Personal., 2017, 45(1), 163-176.

[14] Josiassen A., Assaf A.G., Karpen I.O.: Consumer ethnocentrism and willingness to buy: Analyzing the role of three demographic consumer characteristics. Int. Mark. Rev., 2011, (28)6, 627-646. 
[15] Kottasz R., Bennet R.: Ethnocentric tendencies amongst arts audiences. Int. J. Nonprofit Voluntary Sector Marketing, 2006, 11(4), 303- 317.

[16] Lee W.J., Cheah I., Phau I., Teah M., Elenein B.A.: Conceptualising consumer regiocentrism: Examining consumers' willingness to buy products from their own region. J. Retailing Consumer Services, 2016, 32, 78-85.

[17] Markovina J., Stewart-Knox B.J., Rankin A., Gibney M., de Almeida M.D., Fischer A., Kuznesof S.A., Poinhos R., Panzone L., Frewer L.J.: Food4Me study: Validity and reliability of Food Choice Questionnaire in 9 European countries. Food Qual. Prefer., 2015, 45, 26-32.

[18] Memery J., Angell R., Megicks P., Lindgreen A.: Unpicking motives to purchase locally-produced food: Analysis of direct and moderation effects. Eur. J. Marketing, 2015, 49 (7/8), 1207-1233.

[19] Molnar A., Gellynck X., Vanhonacker F., Gagalyuk T., Verbeke W.: Do chain goals match consumer perceptions? The case of the traditional food sector in selected European Union countries. Agribusiness, 2011, 27 (2), 221-243.

[20] Nijssen E.J., Douglas S.P.: Examining the animosity model in a country with a high level of foreign trade. Int. J. Res. Mark., 2004, 21, 23-38.

[21] Ozimek I., Żakowska-Biemans S.: Determinants of Polish consumers' food choices and their implication for the national food industry. Brit. Food J., 2011, 113(1), 138-154.

[22] Pentz C.D., Terblanche N.S., Boshoff C.: Demographics and consumer ethnocentrism in a developing country context: A South African study. S. Afr. J. Econ. Manag. S., 2014, 17 (4), 412-426.

[23] Rašković M., Ding Z., Škare V., Dosen D.O., Žabkar V.: Comparing consumer innovativeness and ethnocentrism of young-adult consumers. J. Bus. Res., 2016, 69, 3682-3686.

[24] Rudawska E.D.: Customer loyalty towards traditional products - Polish market experience. Brit. Food J., 2014, 116 (11), 1710-1725.

[25] Sajdakowska M., Gutkowska K.: Postawy etnocentryczne konsumentów na rynku żywności, Marketing i Rynek, 2014, 6, 666-678.

[26] Sajdakowska M., Jankowski P., Gutkowska K., Guzek D., Żakowska-Biemans S., Ozimek I.: Consumer acceptance of innovations in food: A survey among Polish consumers. J. Consum. Res., 2018, 17, 253-267.

[27] Seitz C.C., Roosen J.: Does consumer ethnocentrism influence product knowledge? Food Qual. Prefer., 2015, 43, 113-121.

[28] Shimp T.A., Sharma S.: Consumer ethnocentrism: Construction and validation of the CETSCALE. J. Marketing Res., 1987, 24 (3), 280-289.

[29] Smyczek S., Glowik M.: Ethnocentrism of Polish consumers as a result of the global economic crisis. J. Custom. Behav., 2011, 10(2), 99-118.

[30] Szromnik A.: Etnocentryzm konsumencki jako zjawisko społeczne i problem badawczy. W: Konsument - przedsiębiorstwo - przestrzeń. T. 1. Wyd. AE w Katowicach, Katowice 1998, s. 238.

[31] Taborecka-Petrovicova J., Gibalova M.: Measurement of consumer ethnocentrism of Slovak consumers. Int. Rev. Manag. Market., 2014, 4 (4), 247-258.

[32] Vanhonacker F., Kühne B., Gellynck X., Guerrero L., Hersleth M., Verbeke W.: Innovations in traditional foods: Impact on perceived traditional character and consumer acceptance. Food Res. Int., 2013, 54, 1828-1835.

[33] Vanhonacker F., Lengard V., Hersleth M., Verbeke W.: Profiling European traditional food consumers. Brit. Food J., 2010, 112 (8), 871-886.

[34] Vanhonacker F., Verbeke W., Guerrero L., Claret A., Contel M., Scalvedi L., Żakowska-Biemans S., Gutkowska K., Sulmont-Rossé C., Raude J., Granli B.S., Hersleth M.: How European consumers define the concept of traditional food: Evidence from a survey in six countries. Agribusiness, 2010, 26(4), 453-476. 
[35] Wolanin-Jarosz E.: Ethnocentric orientation of Polish and Romanian consumers in the light of CETSCALE research. Sociologie Românească, 2013, XI (2), 76-95.

[36] Yeh C.-H., Chen C.-I., Sher P.J.: Investigation on perceived country image of imported food. Food Qual. Prefer., 2010, 21, 849-856.

[37] Zabrocki R.: Zachowania konsumentów i zjawisko etnocentryzmu konsumenckiego na globalnym rynku żywności. Marketing i Rynek, 2014, 6, 850-865.

[38] Zander K., Hamm U.: Consumer preferences for additional ethical attributes of organic food. Food Qual. Prefer., 2010, 21(5), 495-503.

[39] Żakowska-Biemans S., Pieniak Z., Gutkowska K., Wierzbicki J., Cieszyńska K., Sajdakowska M., Kosicka-Gębska M.: Beef consumer segment profiles based on information source usage in Poland. Meat Sci., 2017, 124, 105-113.

\section{ŻYWNOŚĆ POLSKIEGO POCHODZENIA I JEJ ATRYBUTY W OPINII KONSUMENTÓW}

$$
\text { Streszczenie }
$$

Celem pracy było: (1) określenie profilu społeczno-demograficznego konsumentów zainteresowanych żywnością postrzeganą jako krajowa, (2) określenie, co konsumenci rozumieją pod pojęciem ,żywność pochodzenia polskiego", jak również wskazanie, które atrybuty i w jakim stopniu są przypisywane temu rodzajowi żywności. Badanie przeprowadzono w październiku 2013 r. na ogólnopolskiej populacji 1000 osób. Badanie miało charakter ilościowy i zostało przeprowadzone za pomocą wywiadów bezpośrednich ze wspomaganiem komputerowym (CAPI - Computer Assisted Personal Interviews). Przeprowadzono analizę częstotliwości i obliczono wartości średnie oraz odchylenia standardowe. Aby określić statystycznie istotne różnice między zmiennymi, w badaniu wykorzystano statystykę $\chi^{2}$. Zastosowano również jednoczynnikową analizę wariancji ANOVA oraz test post hoc Tukeya do porównania, czy różnice pomiędzy średnimi są istotne statystycznie. Wykazano, że „żywność pochodzenia polskiego” jest głównie postrzegana jako żywność produkowana w Polsce i z polskich surowców. Respondenci, którzy podkreślali miejsce produkcji jako kluczowe kryterium wskazujące polskie pochodzenie żywności, mieli ponad 61 lat, posiadali wyższe wykształcenie i deklarowali częste podróże za granicę. W większym stopniu polskie pochodzenie surowców zostało docenione przez kobiety, najstarszych respondentów oraz osoby z wyższym wykształceniem. Uzyskane wyniki wskazały, że konsumenci mają zaufanie do żywności postrzeganej jako polska i oceniają ją pozytywnie. Na podstawie uzyskanych wyników otrzymano również informacje, które można wykorzystać w komunikacji skierowanej do starszych konsumentów, których udział w rynku wzrasta z powodu starzenia się społeczeństwa.

Słowa kluczowe: konsument, żywność pochodzenia polskiego, atrybuty żywności, etnocentryzm konsumencki 